ARCHIWUM HISTORII FILOZOFII I MYŚLI SPOŁECZNEJ • ARCHIVE OF THE HISTORY OF PHILOSOPHY AND SOCIAL THOUGHT VOL. 57/2O12 $\cdot$ ISSN OO66-6874
\end{abstract}

JOHANNES ZACHHUBER

\title{
World Soul and Celestial Heat \\ Platonic and Aristotelian Ideas in the History of Natural Philosophy
}

\begin{abstract}
A в S T R AC T: The article considers part of the complex history of the concept of a world soul. Starting from debates in the late 18 th century and especially with the contribution by Salomon Maimon, it is argued that the precise shape of the idea of the world soul encountered there can be explained with the help of a specific intellectual tradition combining Platonic and Aristotelian ideas. Beginning with Themistius in the 4th century there is evidence of a view aligning the theory of a world soul from Plato's Timaeus with Aristotle's idea of celestial heat in De generatione animalium II, 3 . Traces of this syncretistic view, it is then shown, are to be found in Averroes and have later influenced renaissance discussion about the nature and the origin of life. There is some probability that acquaintance with the latter, which can be proved for 18th century thinkers, helps explain the precise shape of the contribution of Maimon and some others.

K E Y W OR D S: world soul • celestial heat $\bullet$ Plato • Aristotle $\bullet$ Kant • Maimon • Themistius • Averroes $\bullet$ Blumenbach $\bullet$ Cardano $\bullet$ panpsychism $\bullet$ Buonamici
\end{abstract}

While the longevity of the notion of a world soul is recognised by scholars of the history of philosophy, the various transformations it underwent in the course of this history are still often neglected ${ }^{1}$. The idea of a world soul has its historical origin or, at least, its classical point of reference in Plato. The vast majority of later references can be traced back, directly or indirectly, to the famous passage in the Timaeus $(34 \mathrm{a}-37 \mathrm{c})$ in which the demiurge as part of his creation of the world forms a soul for it as well ${ }^{2}$. In subsequent development, however, this idea was variously adapted. It was

1 The present article is a revised and translated version of Weltseele und Himmelswärme. Zur Diskussion um den Ursprung des Lebens in der Neuzeit, [in:] I. Hübner/K. Laudien/J. Zachhuber (eds.), Biotechnologie und Selbstverständnis. Hintergründe einer aktuellen Debatte, Münster 2004, pp. 113-130. I would wish to acknowledge my gratitude to $\mathrm{Dr}$ Julia Meszaros for her exacting comments on an earlier draft of this paper.

2 An overview of this history is given in J. Zachhuber, 'Weltseele', [in:] Historisches Wörterbuch der Philosophie, vol. 12, Basel 2004, pp. 516-521. 
aligned to similar, or seemingly similar, concepts; it was influenced or even contaminated by theories from more or less incompatible rival philosophies. In order to understand its continuing use and attractiveness over the centuries, therefore, it is not enough merely to consider its Platonic origin, but its historical transmissions and transformations have to be taken into account as well.

The following attempt to reconstruct one chapter in the complex history of this idea starts from this premise. I intend to show how specifically the interference of the Platonic notion of a world soul with an element of Aristotle's philosophy of nature became influential for philosophical and proto-scientific conceptions about the nature, the origin, and the evolution of life from the $16^{\text {th }}$ to the $18^{\text {th }}$ century.

I shall begin my account of this narrative at its historical end-point - in the late $18^{\text {th }}$ century with its renewed interest in the world soul (1). In a second step, the intellectual constellation encountered in those debates is traced back to a much earlier conflation of Platonic and Aristotelian ideas (2). The resulting notion of world soul is then considered in its impact on Renaissance and Early Modern thought (3). I end with a brief conclusion (4).

\section{Salomon Maimon and the renewed interest in the world soul at the end of the $18^{\text {th }}$ century}

On 15 May 1790, Salomon Maimon (1753-1800) wrote a letter from Berlin, where he was staying at the time, to Immanuel Kant. Born in Poznan into a Jewish family and brought up with Hebrew, which throughout his life felt more familiar to him than German, Maimon had been schooled in the Kabala and influenced specifically by the medieval theologian and philosopher Maimonides (Moses ben Maimon, 1138-1204). Upon his arrival in Berlin, this background made him a fascinating outsider amongst the enlightened and educated public of that city. His critical response to Kant's Critique of Pure Reason had drawn from the celebrated Königsberg philosopher the most enthusiastic praise that 'not only has none of my critics understood me and the main questions as well as Herr Maymon does but also very few men possess so much acumen for such deep investigations as he ${ }^{3}$.

In his letter, Maimon confirms with gratitude the receipt of Kant's Critique of Judgment. With apparent understatement he writes that he has

3 I. Kant, Letter to Markus Herz, 26 May 1789, [in:] I. Kant, Akademie-Ausgabe, vol. 11, Berlin/Leipzig ${ }^{2}$ 1922, 49,12-15. ET: Correspondence, transl. and ed. A. Zweig, Cambridge 1999, pp. 311-2. 
not yet had time to read the book or indeed reflect with care on its contents. One particular idea that has been stimulated by its perusal, however, seems so important to him that he wishes to share it immediately with his famous colleague:

The approbation you bestow on Privy Councilor Blumenbach ${ }^{4}$ induced me to read his excellent little essay and called up an idea in me which, though not new, may seem quite paradoxical, viz., the idea of the world-soul and of how its reality might be determined. I venture to submit my thoughts on this for your examination'.

This Maimon does in the following part of the letter:

The world-soul is a power inherent in matter in general (the material of all real objects), a power that affects matter in general in different ways according to the various ways that matter is modified. It is the ground of the particular sort of matter (even in unorganised matter), the ground of the organisation in every organised body, the ground of the life in an animal, of the understanding and reason in human beings, etc.; in short, the world-soul confers forms on all things according to the constitution of their matter, in such a way that it adapts matter, enabling it to change from a single form, to take on other forms, forms of a higher order. And since matter can undergo unlimited modification, so this entelechy too can supply an unlimited variety of forms. It is thus the ground of all possible agency. I fail to see what might have caused the newer philosophers to repudiate this view entirely ${ }^{6}$.

A number of observations can be made at once on the basis of these lines:

1. Let us first consider the project Maimon proposes to Kant. It is not so surprising considering the latter's appropriation of teleology in his third Critique. The concept developed in this writing of the world as an organic whole does indeed suggest the existence of a principle corresponding to this structure. ${ }^{7}$ Characteristically, Kant recognised the legitimacy of the question but exercised the kind of restraint towards it that was so typical for his general attitude to more 'speculative' ideas. Still, Maimon's proposal is more than yet

4 Cf. I. Kant, Kritik der Urteilskraft $\$ 81$, [in:] idem, Akademie-Ausgabe, vol. 5, Berlin 1908, pp. 424,19-22.

5 S. Maimon, Letter to 1. Kant, 15 May 179o, [in:] I. Kant, Akademie-Ausgabe, vol.11, 174,12-18. ET: Zweig, 351.

6 Tbidem, 174, 22-35; ET: Zweig, 352 (with changes).

7 Cf. here and in the following: K. Düsing, Die Teleologie in Kants Weltbegriff („Kantstudien“, Ergänzungshefte 96), Bonn 1968, pp. 172 and 197-205. 
another variant of early Idealist attempts to 'develop further' Kant's critical philosophy. For he rightly perceives that Kant's critical philosophy opens up the opportunity for a new philosophy of nature precisely by excluding the identification of the principle of the world's teleological unity with God. This is where, for him, the potential of the world soul rests, and for this reason the charge of pantheism against this theory, according to him, is void too:

According to Spinozism, God and the world are one and the same substance. But it follows from the explanation I have given that the world soul is a substance created by God. God is represented as pure intelligence, outside the world [intelligentia pura extramundana]. This world soul, by contrast, is indeed represented as an intelligence but as one that is essentially connected to a body (the world), consequently as limited and as subordinate to the laws of nature ${ }^{8}$.

The explanatory value of the world soul, then, consists in its representation of the quasi-organic unity of the cosmos as its teleological principle ("its entelechy"). In his most extensive treatment of the same topic, Maimon explains that it has to be "one and the same power [...] uniting in its agency ends (Zwecke) and the [mechanical] laws of nature". This universal character of its function means that one and the same principle, precisely the world soul, governs inanimate being as well as vegetative and animal life. Even for human cognition, the world soul is foundational as all individual souls are "various emanations of one and the same source, the universal world soul"1.

2. Maimon considered the topic of the world soul unduly neglected. In this, he clearly referred to the widespread rejection of the notion throughout the $18^{\text {th }}$ century $^{11}$. In 1754, the Orientalist Herman Samuel Reimarus (1694-1768), most famous for his radical contribution to early biblical criticism published posthumously by G.E. Lessing, scathingly dismissed the idea as "an empty tone and a mere refuge of our ignorance": "It does not explain anything and is - like other, similar inventions - [...] a hidden quality (qualitas occulta) ${ }^{\prime \prime 2}$. Reimarus' statement neatly represents the broad consensus of

8 S. Maimon, op. cit. (n. 4), 175,3-9, ET: Zweig, 352.

9 Idem, 'Weltseele', [in:] idem, Philosophisches Wörterbuch, Berlin 1791, pp. 179-208, here: 194 (= Idem, Gesammelte Werke, ed. V. Verra, Hildesheim 1970, vol. 3, pp. 203-232). Here and in the following I use the pagination of the original edition.

10 Tdem, 'Weltseele', p. 191. The epistemological function of the world soul, which is crucial for Maimon, I shall leave aside. Cf. however n. 49 below.

${ }^{11}$ Cf. for this background now the very full account in M. Vassányi, Anima Mundi: The Rise of the World Soul Theory in Modern German Philosophy, Dordrecht 2011.

${ }^{12}$ H.S. Reimarus, Die vornehmsten Wahrheiten der natürlichen Religion, Hamburg 1754, p. $124\left(={ }^{3} 1766\right.$, p. 138$)$. Qualitas occulta was a popular term of abuse during the age of 
a time strongly influenced by Locke and Leibniz, both of whom, in spite of their many disagreements, had discarded this theory tout court ${ }^{13}$. Yet at the time of Maimon's writing, change was in the air. In his celebrated (and to some, notorious) conversation with Jacobi, whose publication in 1785 caused in Goethe's phrase "an explosion"14, Lessing had allegedly said he could only think of God as "the soul of the all"15. In subsequent years, Herder positioned himself along similar lines ${ }^{16}$; Kant's development in the third Critique, as Maimon rightly saw, moved in a similar direction even though the term "world soul" was used regularly only in his Opus Postumum ${ }^{17}$. Maimon's own publications, two major articles developing the plan enunciated in his letter to $\mathrm{Kant}^{18}$. kick-started the renewed reception of the concept, and with Schelling's writing On the World Soul (Von der Weltseele, eine Hypothese der höheren Physik zur Erklärung des allgemeinen Organismus) in 1798 the topic finally was firmly established on the intellectual agenda.

Maimon's interest, then, is representative for a broader development at the time. Yet he does not seem to share the emotional exuberance of early romantic and Idealistic fascination with this topic; for him, much more soberly, the theory of the world soul is of potentially "great value for the enlargement of our understanding of nature"19.

3. Given that this is his explicit concern, Maimon's brief allusion to his source of inspiration, mediated through Kant's Critique of Judgment, deserves attention. It is Johann Friedrich Blumenbach (1752-1840), to whose

enlightenment. The more clear-sighted recognised that their complete purge would destroy scientific explanation altogether. Cf. Voltaire, Élémens de la philosophie de Newton (Euvres de Voltaire, ed. M. Palissot, vol. 32, Paris 1792, pp. 130-1): «Si l'on entend par ce mot un principe réel dont on ne peut rendre raison, tout l'univers est dans ce cas. Nous ne savons ni comment il y a du mouvement, ni comment il se communique, ni comment les corps sont élastiques, ni comment nous pensons, ni comment nous vivons, ni comment ni pouquoi quelque chose existe; tout est qualité occulte».

${ }_{13}$ J. Locke, An essay concerning human understanding III, ch. 10, \$14, London 1894, p. 403. G. W. Leibniz, Nouveaux Essais sur l'entendement humain III, ch. 10, \$14, [in:] idem, Sämtliche Schriften und Briefe, ed. Deutsche Akademie der Wissenschaften zu Berlin, Berlin 1962, vol. VI/6, pp. 343, 28-9.

${ }^{14}$ J.W. Goethe, Aus meinem Leben. Dichtung und Wahrheit, Third Part, Book 15, Weimarer Ausgabe, I 28, 313, 4.

${ }^{15}$ F.H. Jacobi, Über die Lehre des Spinoza in Briefen an den Herrn Moses Mendelssohn, Breslau 1785, p. $75 \mathrm{f}$.

${ }^{16}$ J. G. Herder, Gott 4 (1787). Sämtliche Werke, ed. B. Suphan, Berlin 1877-1913, vol. 16, p. $526 \mathrm{f}$.

${ }_{17}$ K. Düsing, op. cit. (n. 6), pp. 172-205.

${ }^{18}$ S. Maimon, op. cit. (n. 8) and idem, Über die Weltseele (Entelechia universi), „Berlinisches Journal für Aufklärung" VIII/1 (1790), pp. 47-92.

19 Idem, 'Weltseele', op. cit. (n. 8), p. 208. 
work Maimon claims to have been directed by his supposedly preliminary reading of Kant's book. Blumenbach was a major naturalist of his time, whose studies in anthropology were widely appreciated; but it is with his work on Bildungstrieb (nisus formativus, "formative impulse") that he contributed to contemporary debates on the nature and the origins of life"20. Closer scrutiny reveals that Maimon's reference to Blumenbach's work in his letter to Kant is by no means the mere product of politeness or flattery. In his essays on the world soul, Maimon draws heavily on Blumenbach; in fact, their sections on natural philosophy are largely extracted from Der Bildungstrieb.

What, then, connects Blumenbach's work with the theory of the world soul? Why would Maimon's reading of Der Bildungstrieb induce him to renew this kind of philosophical speculation? In fact, there is, at first sight, no indication that Blumenbach himself had any interest in this notion. He refers, in a note, to the 1782 Latin dissertation of a certain Adam Michael Birkholz (1746-1818) who, in his later life, became a noted alchemist and who had drawn a parallel between Blumenbach's scientific work and the Platonic tradition of natural philosophy ${ }^{21}$. Blumenbach, however, did not take this as a compliment, but remarks with evident sarcasm:

Since more recently critical acumen has been able to find animal response to stimuli prefigured in Homer and Harvey's blood circulation described in the book of Ecclesiastes, it would be altogether bad if not the whole [theory of] nisus formativus [sc. formative impulse] could with some effort be extracted from all the works about generation that have been written over the past 2000 years and which, taken together, by now have grown into a not inconsiderable library ${ }^{22}$.

His proper concern is the controversy in natural philosophy between the theories of epigenesis and evolution. The latter does not, of course, refer to Darwin's later theory; Blumenbach describes this view as follows:

${ }^{20}$ For a full account of his life cf. Blumenbach's entry in: Historische Commission bei der Königl. [sc. Bayerischen] Akademie der Wissenschaften (ed.), Allgemeine Deutsche Biographie, vol. 2, Leipzig 1875, pp. 748-752. For an informed summary of his theory of Bildungstrieb see further: T. Lenoir, The Strategy of Life. Teleology and Mechanics in Nineteenth Century German Biology, Chicago 1982, ch. 1; R.J. Richards, The Romantic Conception of Life: Science and Philosophy in the Age of Goethe, Chicago 2002, pp. 216-222. More recently, Blumenbach has also been considered in the context of the early history of the concept of race. For this cf. S. Eigen/M.J. Larrimore (eds.), The German Invention of Race, Albany 2006.

${ }^{21}$ A.M. Birkholz, Disputatio de respiratione eiusque fine summo atque ultimo, Leipzig 1782, $\$ 5$, p. 15.

${ }^{22}$ J.F. Blumenbach, Über den Bildungstrieb, Göttingen 1789, ${ }^{2} 1791$, p. 35 f. 
[This theory rejects] all actual generation in the world and [believes] instead that the seeds for all human beings, animals and plants that have ever lived and will ever live were made in the first creation so that now one generation after another can merely evolve. This is why it is called the theory of evolution ${ }^{23}$.

The theory of epigenesis, on the other hand, assumes that

[...] the parents' mature but otherwise raw and unformed generative matter when, at the right time and under the necessary conditions, it has reached its place of destination, is then successively formed into the $\left[\right.$ new] creature $^{24}$.

The discovery of sperm cells in 1677 had seemingly yielded the upper hand to the theory of evolution, but it is Blumenbach's intention to redress the balance by offering a stinging critique of the latter; it is this argument which Kant cited with approval in his Critique of Judgment ${ }^{25}$. His own experiments, Blumenbach claims, have lent support to the epigenetic hypothesis:

No preformed seeds pre-exist; but in the generative matter of organised bodies, which was previously raw and unformed, there arises, once it has reached maturity and its place of destination, a special impulse (Trieb) that continues throughout their lives and causes them to take on their specific form, to retain it throughout their lives and, in case they are at all mutilated, to restore them to it wherever possible $e^{26}$.

This impulse, a kind of vital force, Blumenbach calls "formative impulse" (Bildungstrieb).

Maimon observes that in this scientific theory an internal cause, rather than an external one, is offered to explain the functioning of organisms. He agrees that such an explanation is indeed needed here: an external cause or form would only "lead to an aggregate of parts of matter" if one accepts that internal forms are necessary for our understanding of things, then the question arises how these forms come about. As they are

${ }^{23}$ Tdem, op. cit., 14. Cf. idem., Handbuch der Naturgeschichte, Göttingen 1779, p. 17 ff.

${ }^{24}$ Tdem, op. cit. (n. 19), pp. 13-4.

${ }^{25}$ I. Kant, Kritik der Urteilskraft $₫ 81$, Akademie-Ausgabe, vol. 5, 424, pp. 7-34. Kant had previously supported the theory of seeds (Keime) which Blumenbach rejected. Cf. R. Bernasconi, Kant and Blumenbach's Polyps: A neglected chapter in the history of the concept of race, [in:] Eigen/Larrimore, op. cit., pp. 73-89.

${ }^{26}$ J.F. Blumenbach, op. cit. (n. 19), pp. 31-2.

${ }^{27}$ S. Maimon, 'Weltseele', op. cit. (n. 8), p. 189. 
evidently indivisible, they themselves cannot originate through successive development according to mechanical laws. Neither can they emerge from other, different forms: "They must have the cause of their existence either in themselves, in which case they are substances, or in something external to them ${ }^{28}$ ". The former of these possibilities, according to Maimon, is held by the school of Leibniz and Wolff, the latter by "the Aristotelian School", which [...] assumed a universal form existing separate from all matter and imparting onto the specific bodies their specific forms"29.

This precisely is the world soul, and Maimon after careful examination of both positions and their arguments, concludes that this theory does indeed offer the best explanation of natural phenomena.

\section{Historical background: a late ancient harmonisation of Plato and Aristotle and its medieval reception}

If one searches for the background of Maimon's theory in the history of ideas, the first rather astonishing observation is that this philosopher ascribes the hypothesis of a world soul to - as he calls it - the Aristotelian School. Intuitively, this seems rather implausible. We have already seen that term and concept go back, rather, to Plato's late dialogue Timaeus, where the world soul is formed by the demiurge in order to guarantee the quasiorganic unity of the world and facilitate knowledge and motion. Thus far, at least its characterisation by Maimon as "created intelligence" might seem to have support in this text.

Aristotle, on the other hand, omits the world soul from his cosmology; in fact, not only does he omit it, but quite clearly such an entity could never have a place in his philosophy. Firstly, the Stagirite consciously limits the existence of souls to animate being - plants, animals and human beings. The cosmological and epistemological functions of Plato's world soul, secondly, he ascribes to the unmoved mover, which in some ways is its conceptual counterpart (the world soul moves as eternally self-moving ${ }^{30}$ !). Thirdly and finally, the unmoved mover is not different from God, hence while there may be no danger here of "pantheism", one certainly could not speak of "created intelligence" either.

Still, it would be facile to conclude that Maimon was quite simply disoriented in the history of philosophical ideas and merely confused Plato with Aristotle. For it is evident from his account that Aristotelian philosophy

\footnotetext{
${ }_{28}$ Tbidem, p. 190.

29 Tbidem.

${ }^{30}$ Plato, Laws X, 896 a.
} 
with its complementary duality of matter and form provides the frame in which he reconstructs the originally Platonic conception of the world soul. Certainly, nothing may be further from Aristotle's own intention than Maimon's claim that "matter and form" are "completely heterogeneous things" ${ }^{\prime 1}$, and the "formal and final cause of all objects" ${ }^{\prime 2}$ is, if anything, the unmoved mover, not the world soul. We must not forget, however, that in the course of the century-long reception history of Platonic and Aristotelian philosophies the two have variously interacted and been combined in ways that may make statements such as these appear meaningful. It may be rash, then, to dismiss Maimon's whole argument on account of its lack of explicit references to the Timaeus, as some scholars have done ${ }^{33}$. For by insisting on such philological purity one may well lose sight of potentially interesting ideas facilitated precisely by means of such "eclecticism". I therefore propose to ask specifically for the historical origin of the Aristotelian interpretation of Platonic doctrine that seems indicated in Maimon's account. It will turn out that this specific interpretation has had a rather long and distinguished history and exercised considerable influence.

The first relevant testimony is found in Themistius, a rhetorician from Constantinople (c. 317-388) and author of paraphrases of Aristotle's writings which combined a summary of their argument with an elementary commentary. Of his paraphrase of Aristotle's Metaphysics only the twelfth book is extant and only in a Hebrew version translated from the Arabic. In the third chapter of this book, Aristotle had explained to his readers why Forms, as stipulated by Plato and his School, were unnecessary. All that was needed to understand the being of a particular individual, for example a human being, was knowledge of its progenitor or parent. For a human being, as Aristotle famously declared, it was most characteristic to have been begotten by a human being ${ }^{34}$.

Themistius, however, does not fully agree and tries to criticise Aristotle on the basis of the latter's own teaching elsewhere. While it was right, he argues, that only a human being (more precisely of course two of them) is needed to explain how a man is begotten, there are other, less straightforward cases:

${ }^{31}$ S. Maimon, 'Weltseele', op. cit. (n. 8), p. 190.

${ }^{32}$ Tbidem, p. 194.

${ }^{33}$ J.-L. Vieillard-Baron, D'une Weltseele (1798) à l'autre ou du kantisme à l'ésotérisme dans la conception schellingienne de la nature, [in:] Studi urbinati di storia, filosofia e letteratura 6o, nuova serie B, (1977), pp. 395-457, here: pp. 401-404.

${ }^{34}$ Aristoteles, met. $\Lambda_{3}, 1070^{\mathrm{a}} 27-30$. 
The author [sc. Aristotle] failed to consider the large number of creatures originating from others unlike them. Thus we observe a kind of wasps originating from the bodies of dead horses and bees from the bodies of dead cattle ${ }^{35}$. We see frogs originating from rot and midges from fermented wine. Thus we note that nature does not generate these beings from a form similar to their own ${ }^{36}$.

Themistius here refers to the problem of so-called spontaneous generation (generatio aequivoca), which he implies Aristotle himself describes and distinguishes from the normal case where like is brought forth by like ${ }^{37}$. In those cases at least even Aristotle must admit that another factor beside "parents" has to be taken into account in order to explain the generation of new life. And, Themistius adds, this is indeed what Aristotle does. Only several lines further down in the same book he names beside the parents (more precisely, the father) also sun and ecliptic (loxòs kýklos) as causes for the individual human being $\left(1071^{\mathrm{a}} 15 \mathrm{f}\right.$.). More remarkable and surprising is that Themistius goes further by identifying these Aristotelian ideas with a characteristic element of Platonic doctrine:

This proves that these 'proportions' [sc. the germinal powers necessary for individual generation; Greek: logoi] are brought about by a cause which is the greatest and most eminent of them all: the soul of the earth which, according to Plato is produced by the secondary gods and, according to Aristotle, by sun and ecliptic ${ }^{38}$.

One would hardly overstate matters by calling this passage mysterious. If the "secondary gods" are the created gods of the Timaeus (39d-41e), the soul of the earth cannot be the world soul. Themistius in at least one place draws a clear distinction between the two and only identifies the latter with intellect (nous) 39“ $^{\text {" }}$ However, elsewhere he is less careful and in one central passage, which also is rather similar to the one quoted above, he seemingly identifies the two ${ }^{40}$. Yet this is nothing in comparison to the

35 A well known theory in antiquity; cf. e.g. Virgil, Georgics IV, 1l. $300 f f$.

${ }^{36}$ Themistius, In Aristotelis metaphysicorum librum $\Lambda$ paraphrasis, ed. S. Landauer, Berlin 1903, ז,28- ח,2. For my translation I have generally preferred Averroes' version of the passage: Averroes, Tafsīr mā ba'd at囚-T冈abī'at (Long Commentary on Metaphisycs), ed. M. Bouyges, Beirut 1938-1948, here: 1492,3-10. I use the French translation by A. Martin, Averroès. Grand Commentaire de la Métaphysique d'Aristote, Livre Lam-Lambda, Paris 1984, pp. 128-9.

37 For example at Aristotele, Historia animalium V 1, 539 $15-25 ; 19,550^{\mathrm{b}} 30-551^{\mathrm{a}} 8$.

${ }^{38}$ Themistius, In met. $\Lambda, \pi, 18-21$ Landauer = Averroes, Tafsīr, 1494,4-7 Bouyges.

39 Themistius, In libros de anima paraphrasis, ed. R. Heinze Berlin 1899, 20,19-25.

40 Themistius, In de anim., 26, 25-30 Heinze. 
riddle of his Aristotelian reference. What do "sun and ecliptic" generate that is, in effect, similar to Plato's world soul? No answer to this question is given in Themistius' text, but it appears not unlikely that he here thinks of celestial heat (calor coelestis), a marginal and rather dark element of Aristotle's natural philosophy ${ }^{41}$. Its obscure character, however, may have made it all the more appealing to those who expected to discover the most important information hidden in equivocal allusions. The Stagirite philosopher in some places mentions the heat within the seed as necessary for the generation of life $e^{42}$. The origin of this heat, he argues in a celebrated passage in the second book of his work On the Generation of Animals, is not the fiery element, but it is "analogous to the element of the stars" $\left(736^{\mathrm{b}} 37\right)$. It seems likely then that Themistius' remark is based on an interpretation that connects the mention of "sun and ecliptic" in Metaphysics XII with the doctrine of celestial heat from the Generation of Animals and on this basis constructs a parallel between Aristotle's teaching and Plato's theory of the world soul.

Recalling Maimon's argument, it is remarkable that the specific problem Themistius has in mind here is the generation of individual life; this, he argues, cannot be explained without reference to a world soul or to celestial heat respectively. It was the same question that formed the starting point for Maimon's deliberation. He too, interestingly, mentions spontaneous generation as at least one major argument in favour of the existence of a world soul ${ }^{43}$.

The very nearly casual way in which Themistius introduces and presents his remark makes it not improbable that others before him made the same or a similar move, but we know little about any such prehistory of this piece of Platonic-Aristotelian exegesis or indeed of the more immediate reception of Themistius' ideas ${ }^{44}$.

From its textual transmission alone it is evident that Themistius' paraphrase was known in the Arab world. It is not so surprising then that the next major reference to our passage together with an extensive discussion of its ideas occurs in Averroes' (Ibn Rušd; 1126-1198) Long Commentary on

${ }^{41}$ Its primary significance is in the physics of celestial bodies: how do they produce heat? Cf. J. Zabarella, De calore coelesti, [in:] idem, De rebus naturalibus libri XXX, Cologne, ${ }^{4}{ }_{1602}$, pp. 555-582.

${ }^{42}$ Aristoteles, De generatione et corruptione II 9-11; De generatione animalium II 3; De caelo II 7.

${ }_{43}$ Maimon, 'Weltseele', op. cit., p. 207.

${ }^{44}$ Cf. however Nemesius von Emesa, De natura hominis 43, ed. M. Moreno, Leipzig 1987, pp. $126,4-7$. 
Aristotle's Metaphysics ${ }^{45}$. Averroes, who strives for a strict Aristotelianism, is unconvinced by Themistius' critique of the Stagirite and uses his text, which he cites in full, as a starting point for a robust defence of what he considers Aristotle's actual position. It soon becomes clear that the addressee of this defence is not so much Themistius as orthodox Islamic theology of creation. Core to Averroes' reading of Aristotle is the assumption, which is indubitably historically correct, that Aristotle's forms are strictly immanent and hence must not be conflated in any way with Platonic Forms.

The subtle details of Averroes' argument in this passage, which according to Ernest Renan offers a summary of his whole philosophy ${ }^{46}$, are beyond the scope of the present investigation. The following observations, however, are significant ${ }^{47}$ :

1. In his interpretation of Themistius' passage, Averroes takes it for granted that it refers on the one hand to Plato's concept of the world soul ${ }^{48}$ and, on the other, to Aristotle's On the Generation of Animals II 3 and thus to the theory of celestial heat. In fact he discusses the latter text at some length in order to refute Themistius' "Platonising" interpretation and suggest a more appropriate one. Thus, Averroes offers the first explicit testimony for the identification of world soul and celestial heat - even though he himself rejects it.

2. For Averroes himself the real issue is the proper understanding of creation including what we call providence. In other words, his interest is to mediate natural causation with the ultimate sovereignty of an external, transcendent cause, namely God. He distinguishes between two fundamentally different views (and three further mediating ones): the theory of "latent creation" assumes that God created everything fully in the beginning so that subsequent history is merely the unfolding of his principal act. According to "absolute creation", on the other hand, God creates everything - and to be precise we ought to say every single act - exactly when and where it occurs ${ }^{49^{\prime c}}$. While Averroes goes on to characterise the positions of both Aristotle and Themistius as more moderate and hence as lying between these

${ }^{45}$ Averroes, Tafsīr, 1491,4-1505,6 Bouyges. Cf. also the influential Latin translation in Aristotelis Opera cum Averrois commentariis (Venice 1562-1574, Reprint 1962) vol. 8, 303 E - 305 I.

${ }^{46}$ E. Renan, Averroès et l'Averroïsme (1852), Paris [ca. 1869], p. 111.

${ }^{47}$ Cf. on this section: Renan, op. cit., pp. 108-115; M. Allard, Le rationalisme d'Averroès d'après une étude sur la création, "Bulletin d’Études Orientales" 14 (1952-54), pp. 7-55, here: $36-40$.

${ }^{48}$ Cf. his reference to Themistius' De anima paraphrase (1497, 2-7 Bouyges).

${ }^{49}$ This, according to him is the position of Islamic as well as Christian theologians. Of the latter, he explicitly mentions John Philoponus (Averroes, Tafsìr, 1498, 4-6 Bouyges). 
two extremes, the parallel to the dichotomy of evolution and epigenesis in Maimon (who drew on Blumenbach for it) is striking.

3. A further detail may also be significant. Maimon several times writes that the world soul "imparts" or "gives" forms to the individuals". Aver roes in the present passage sharply rejects those who postulate a "Giver of Forms". For him, this is more or less tantamount to an affirmation of the world soul ${ }^{51}$. Apart from Themistius, whom he credits with such an assumption, Averroes explicitly mentions Avicenna (Ibn Sīna, 980-1037) ${ }^{52}$ for whose thought this phrase (wāhib as冈-s囚uwar) was indeed seen as typical $^{53}$.

All these observations taken together serve to make plausible, I believe, the assumption that in Themistius and Averroes we encounter a tradition in which the world soul is described with a combination of Platonic and Aristotelian notions similar to what one later will find in Maimon. I name the following features of this eclectic theory:

1. Aristotle's remarks about celestial heat and its role in the formation of individual life (de generatione animalium II 3) is harmonised with Plato's theory of a world soul. In Maimon, admittedly, only the result of this harmonisation is encountered, but no reference to celestial heat.

2. The most prominent example to illustrate the significance of the world soul is the generation of individual life. This would seem surprising given that is not Plato's concern where he deals with the world soul, but becomes intelligible once one recalls that this precisely is Aristotle's topic in Generation of Animals II 3.

3. Maimon describes the world soul, in Aristotelian language, as a separate Form that "gives" individuals their respective, immanent forms. This corresponds exactly to the view Averroes ascribes to Themistius and Avicenna, but rejects as un-Aristotelian.

${ }^{50}$ Maimon, 'Weltseele', op. cit. (n. 8), p. 179 and 190.

${ }^{51}$ Averroes, Tafsīr, 1496, 2-5 Bouyges.

${ }_{52}$ Averroes, Tafsìr, 1498, 15-17 Bouyges.

${ }_{53}$ Cf. D.N. Hasse, Avicenna's De Anima in the Latin West. The formation of a Peripatetic Philosophy of the Soul 1160-1300, London/Turin 2000, p. $188 \mathrm{f}$. It seems likely then that there are connections as well to the Arabic tradition of the theory of active intellect (cf. Maimon's mention of 'created intelligence'). Avicenna occasionally identified world soul (nafs al-囚ālam) and active intellect. Cf.: Fì ițbāt an-nubuwwāt. Proof of Prophecies, ed. M. Marmura, Beirut 1968, 44. ET: R. Lerner/M. Mahdi (eds.), Medieval Political Philosophy, Ithaca 1963, p. 114. 
4. The paradigmatic example cited regularly for the necessity to postulate an external cause of individual generation is spontaneous generation as, for example, the (alleged) generation of frogs from rot.

This reconstruction of the background to Maimon's theory gains further plausibility once one recalls his intellectual upbringing in the Jewish tradition. Nowhere else was Averroes as influential as among medieval Jewish writers. His work was popularised by means of Hebrew translations, paraphrases and commentaries. Renan estimated that only biblical books were more frequently encountered in medieval Hebrew manuscripts than the writings of the philosopher from Cordoba ${ }^{54}$. Considering this extensive reception, it seems a distinct possibility that Maimon was acquainted with the very passage from Averroes' Long Commentary discussed above even though, on balance, it is more likely that his knowledge was mediated by the writings, for example, of Rabbi Moses Narboni (1300-1362) whom Maimon seems to have known extremely wells5.

\section{World soul and celestial heat in Renaissance and Early Modernity}

Let us, however, leave this specific question to one side and admit that, for the time being, the precise background to Maimon's version of the theory remains unknown to us. The harmonisation of Plato's theory of the world soul with Aristotle's notion of celestial heat had considerable influence in Renaissance and Early Modernity, and this later reception is worthy of some further attention. It is of some significance for the history of early modern science and will thus take us back to the starting point of this investigation in the late $18^{\text {th }}$ century.

Undoubtedly, the $16^{\text {th }}$ century was one of the periods during which interest in the world soul was at its most intense. This theory appeared to serve well the dual fascination of leading thinkers from that age combining a commitment to science or philosophy of nature with a strong sense of the spiritual unity of the world. Accordingly, speculations about the world soul are ripe in authors such as Heinrich Cornelius Agrippa von Nettesheim (1486-1535) and Giordano Bruno (1548-1600) who apply them to subjects such as panpsychism, astrology or alchemy.

Fundamentally, the equation of soul and life is still accepted at this time. Yet it is complemented and partly challenged by the further axiom that

${ }^{54}$ Renan, op. cit. (n. 37), p. 84.

${ }_{5}$ Cf. M.-R. Hayoun, Les Lumières de Cardoue à Berlin. Une histoire intellectuelle du judaïsme, vol. 2, Paris 1998, p. 184. On Narboni's reception of Averroes cf. by the same author: La Philosophie et la Théologie de Moïse de Narbonne, Tübingen 1989. 
life is connected with heat. Hence philosophers and scientist, usually medics, studying the nature and origin of life emphasise both concepts and, in fact, frequently oscillate between them ${ }^{56}$. Prominent example for this practice is Girolamo Cardano (1501-1576), a man whose changeable career and vast variety of interests, ranging from mathematics and medicine to technology, astrology and natural philosophy, make him the perfect epitome of his ages7.

For Cardano, soul and heat are identical in their explanatory function. Even in his own time, this stark claim provoked the question what, if anything, such a fundamental hypothesis explained. Writes the sceptical medic Gabrielle Fallopia, professor at Padua, "When he [sc. Cardano] later says that heat is soul or the instrument of soul, I say that up until now it has not been explained what soul is, let alone what heat is" 58 . Cardano draws on the theory of celestial heat, but radicalises it making calor coelestis the single source of heat and, ultimately, the single active principle of the universe ${ }^{59}$. That he immediately connects this theory with the generation of individual life may at this point no longer surprise us. Given the overall tendency of his version of this theory, it is only consistent that for him all generation, in principle, is spontaneous. For it is celestial heat that as the active principle facilitates the generation of all life ${ }^{60}$.

While tracing back all heat to celestial heat as its origin, Cardano also identifies the latter with soul, evidently the world soul: "There is no heat that does not come from the heavens and therefore from the soul or from light ${ }^{61}$ ". A little further on in the same book we read:

Thus the substance of soul is explained as consisting in a certain celestial heat. [...] For all celestial heat creates, destroys and is soul, instrument of soul or cause of soul. But it is not the instrument of soul because it is earlier, nor its cause because it is in rest, thus [it is] soul ${ }^{62}$.

${ }^{56}$ Cf. M. Mulsow, Frühneuzeitliche Selbsterhaltung. Telesio und die Naturphilosophie der Renaissance, Tübingen 1998, pp. 201-250.

57 On Cardano more generally cf. A. Grafton, Cardano's Cosmos. The Worlds and Works of a Renaissance Astrologer, Cambridge, Mass. 1999.

${ }^{58}$ G. Fallopia, De metallis atque fossilis, [in:] Opera genuina omnia, Venice 1606, vol. 1, p. 347. I quote from Mulsow, op. cit., p. 202.

59 I. Schütze, Die Naturphilosophie in Girlamo Cardanos De subtilitate, Munich 2000, pp. 111-113.

${ }^{60}$ Tbidem, p. $113 \mathrm{f}$.

${ }^{61}$ G. Cardano, De subtilitate II, [in:] Opera omnia, ed. Ch. Spon, vol. 3, Lyon 1663, 374b. This text, as well as the two following quotations, is absent from the first edition of the work (Nuremberg 1550), cf. Schütze, op. cit. (n. 56), pp. 119-20, 124.

${ }^{62}$ G. Cardano, De subtilitate II, op. cit., $388 \mathrm{a}-\mathrm{b}$. 
Cardano is evidently part of the exegetical tradition connecting Plato's world soul with Aristotle's ideas about celestial heat. While his starting point and the overall frame of his argument are more Aristotelian than Platonic, he makes two major adjustments that cannot be reconciled with Aristotelian principles yet are of fundamental significance for the overall shape of his thought. They betray, I think, the specific influence of the world soul tradition.

1. The assumption that celestial heat (or world soul) is the one, unifying principle of the world leads to a homogeneous conception of the cosmos that is substantially different from Aristotle's model of celestial spheres. At the same time, the assumption of the world's homogeneity was a major intellectual presupposition for the rise of modern science. This link between Cardano's theory and the emergence of modern science is not belied by the fact that his favourite application of this insight was astrology.

2. A consequence of the universal role of celestial heat was Cardano's affirmation of panpsychism: "Therefore, Anaxagoras says not inappropriately that all is intermingled and endowed with soul"63.

Such a commitment evidently has far-reaching consequences for the concept of nature; it will emphasise continuity between its various forms and developments and inform scientific study as well as human self-reflection.

A careful and more extensive study of this period would confirm and differentiate the insights gained from the example of Cardano. Within the confines of the present essay such a full examination is not possible. A brief look at one of his contemporaries will nevertheless be helpful and at the same time take us back to our starting point in the late $18^{\text {th }}$ century.

The Florentine scholar Francesco Buonamici (1533-1603) was a much stricter Aristotelian than Cardano ${ }^{64}$. In the fourth book of his treatise $\mathcal{D} e$ alimento, which in its entirety discusses the formation of the foetus, he dedicates a full chapter to the problem of the life force (vis formatrix) responsible for growth and formation of the embryo. Once again, the influence of the Platonic-Aristotelian trajectory combining world soul and celestial heat is evident in this text ${ }^{65}$. Both Themistius and Averroes are mentioned ${ }^{66}$. As one would expect of a self-confessed Aristotelian, Buonamici starts from Aristotle's position; he quotes the classical passage from The Generation of

${ }^{63}$ G. Cardano, De subtilitate II, op. cit., 388b. Cf. also De subtilitate V, op. cit., 439b-440a with references to Aristotle, De gen. animal. II 3.

${ }^{64}$ Cf. on Buonamici: M.O. Helbing, La filosofia di Francesco Buonamici, professore di Galileo a Pisa, Pisa 1989.

${ }_{65}^{65}$ F. Bonamico, De alimento, Florence 1603, IV 19, pp. 527-531.

${ }^{66}$ Tbidem, p.529. 
Animals II 3 in full at the outset of his own discussion. He then considers counter-arguments proffered by certain recent Peripatetics who have decided to follow Plato rather than Aristotle on this topic and effectively affirm the hypothesis of a world soul as necessary to explain origin and development of individual life ${ }^{67}$. Buonamici disagrees with them arguing that the transcendent spirit (animus, spiritus) mediated through celestial heat could, in the semen, effect the transformation of the (female) matter into an ensouled being ${ }^{68}$.

Buonamici, who at the University of Pisa was Galileo's teacher, today is scarcely remembered. This was still different in the $18^{\text {th }}$ century. Blumenbach's book Über den Bildungstrieb, the very writing that inspired Maimon's speculation about the world soul and which at first sight seems entirely detached from the pre-scientific attitude of earlier centuries, contains a reference to Buonamici's work which indicates that the Göttingen naturalist was well aware of the Florentine's writing. In fact, the reference is both specific and appreciative. Blumenbach, as I mentioned earlier, mocks those contemporaries who sought to align any new scientific discovery with traditional knowledge. They fail to see he argues that, conceptual similarities notwithstanding, scientific precision on the basis of the experimental method is a more recent achievement:

I would be delighted if they could present a single one of the older authors who offers a reasonably accurate conception of their 'plastic force' according to the phenomena involved with generation in the way I have attempted to give it of the 'formative impulse' in the present pages ${ }^{69}$.

It is interesting, then, that the one author who is at least partly exempted from this comprehensive dismissal is none other than Buonamici. The "well-known Aristotelian" has expressed himself "quite distinctly" about the vis formatrix, Blumenbach writes in a note on the same page. The note then goes on with a lengthy quotation precisely from De alimento IV 19.

Blumenbach thus, in spite of his protestations, was certainly aware of the older debate in natural philosophy concerning celestial heat and the world soul. He would have known, too, about the parallel between the scientific controversy about evolution and epigenesis and the earlier theological and philosophical debate concerning latent and absolute creation. Maimon's reading of his book, then, is less off the mark than might appear at first sight,

${ }_{67}$ Tbidem, pp. 529-531.

${ }^{68} \mathrm{Cf}$. the summary of his own position at the beginning of the chapter: ibidem, pp. $527-8$.

${ }^{69}$ J.F. Blumenbach, op. cit., pp. 37-8. 
even though Blumenbach would, intuitively, have agreed with Buonamici against the Platonic twist Maimon proposes to give to the debate. Still, considering the intellectual background as well as the character of Blumenbach's argument, Maimon's perception that it can and ought to be integrated into a broader philosophical debate, is by no means absurd. Philosophy and the sciences at the end of the $18^{\text {th }}$ century are still quite close, even though the parting of the ways, which was to become increasingly marked during the following century, is increasingly apparent.

\section{Conclusion}

The idea of a world soul flowing originally from Plato's Timaeus has over the centuries influenced many and various debates. The purpose of this present paper was a partial clarification of its reception history. I have shown how a particular reading of this theory, intent to align it with Aristotelian natural philosophy and specifically with his theory of celestial heat, led to its application to the problem of the origin of individual life. The interference of two ultimately very different conceptions provided for a variety of articulations. Some authors would come down more on the Platonic, others more on the Aristotelian side; the need to take into account theistic theologies of creation in Islam and Christianity was a further influential factor. Remarkable is the close proximity between philosophical and theological concerns on the one hand, and proto-scientific ones, whether physical, biological or medical, on the other. This close conjunction, it appeared, was not radically discontinued until the turn of the $19^{\text {th }}$ century when ideas about the world soul in combination with Aristotle's celestial heat were still reappropriated along with the emergence of the natural science of Romanticism. Yet neither Maimon nor Schelling are pioneers of this new science; they are remembered today as philosophers while Blumenbach and his colleagues would rightly insist that the precision of their scientific explanation and not their detailed acquaintance with the learning of past ages would constitute the criterion by which their work ought to be measured.

Johannes Zachinder - Wykładowca teologii na Uniwersytecie w Oxfordzie. Stopnień doktora zdobył na podstawie pracy „O naturze ludzkiej u Grzegorza z Nyssy”. Po ośmiu latach pracy akademickiej na Uniwersytecie Humboldta w Berlinie, został w 2005 roku członkiem Trinity College w Oxfordzie jako wykładowca teologii.Prowadzi także zajęcia ze współczesnej teologii chrześcijańskiej na Wydziale Teologicznym Uniwersytetu w Oxfordzie. Jego publikacje dotyczą relacji pomiędzy filozofią a teologią w myśli późnoantycznej oraz współczesnej tradycji europejskiej, a także rozwoju teologii w XIX i XX w. oraz sekularyzacji, religii i polityki, pojęcia ofiary. Pełni również obowiązki dyrektora Ian Ramsey Centre for Science and Religion w Oxfordzie. 
JOHANNES ZACHHUBER - Reader of Theology at the University of Oxford. He earned his D.Phil. in theology (Oxford 1997) with a thesis on Human Nature in Gregory of Nyssa. After eight years at Humboldt University, Berlin, he took on his current position as Fellow of Theology at Trinity College Oxford in 2005. He also teaches Modern Christian Theology in the Theology Faculty at Oxford. He has published on the relation of philosophy and theology in late antiquity and in the more recent Continental tradition, on the development of theology during the 19th and 2oth century, on secularisation, religion and politics, and the notion of sacrifice. He is Acting Director of the Ian Ramsey Centre for Science and Religion at Oxford. 
